\title{
Trace metals in porewater of surface sediments and their bioavailability in Jiaozhou Bay, Qingdao, China
}

\author{
Siyuan Ye $\cdot$ Edward A. Laws $\cdot$ Xigui Ding $\cdot$ \\ Hongming Yuan · Guangming Zhao • \\ Jin Wang
}

Received: 26 January 2009/Accepted: 16 August 2010/Published online: 22 September 2010

(C) The Author(s) 2010. This article is published with open access at Springerlink.com

\begin{abstract}
Samples of porewater and the edible tissue of mottled clams, Ruditapes variegatus, were collected simultaneously at each of 12 stations from Jiaozhou Bay near Qingdao, China, in June of 2003. Chemical analysis focused on trace metals and major elements. Porewater concentrations of $\mathrm{Cd}, \mathrm{Cr}, \mathrm{Pb}$, and $\mathrm{Zn}$ were distributed in a bimodal fashion among the 12 stations, with mean concentrations at six of the stations being 8-32 times mean values at the other six stations. The concentrations of the same metals in clams were remarkably similar among stations, the coefficients of variation being only $12-37 \%$. Calculations performed with the computer program PHREEQC indicated that $\mathrm{Pb}$ and $\mathrm{Cr}$ in porewater were present only in the +2 and +3 states, respectively, and because dissolved $\mathrm{Cd}$ and $\mathrm{Zn}$ exist only in the +2 state, the bimodal distribution of these four metals likely reflects secondary effects associated with their scavenging by $\mathrm{Fe}$ and/or Mn under oxidizing conditions and subsequent dissolution in the reducing environment of the porewaters. Consistent with this hypothesis is the fact that the distribution of high and low metal concentrations was closely correlated with the granularity of the sediment, with lower
\end{abstract}

S. Ye $(\bowtie) \cdot$ X. Ding $\cdot$ H. Yuan · G. Zhao · J. Wang

Key Laboratory of Marine Hydrocarbon Resources and Environmental Geology,

Qingdao Institute of Marine Geology,

Ministry of Land and Resources,

Qingdao 266071, People's Republic of China

e-mail: siyuanye@hotmail.com

E. A. Laws $(\square)$

Louisiana State University,

Baton Rouge, LA 70803-4110, USA

e-mail: edlaws@1su.edu metal concentrations associated with relatively coarse sediment. Comparison of published biological concentration factors with the ratios of metal concentrations in the clams to porewater metal concentrations indicated that the porewaters were not the primary sources of the metals in the clams. Mixing processes in the bay likely account for the rather uniform concentrations of metals in clam tissue.

Keywords Trace metals - Bioavailability - Species . Porewater - Geochemical modeling · Jiaozhou Bay · China

\section{Introduction}

Many marine organisms have the potential to bioconcentrate high levels of metals from their growth environment (EI-Moselhy and Gabal 2004; Heier et al. 2009; Szeffer et al. 1999). Metal bioaccumulation by marine organisms has been the subject of considerable interest in recent years because of concern that high levels of metals may have negative effects on marine organisms and may create serious problems with respect to their suitability as food for humans (Franco et al. 2007).

The highest concentrations of metals in aquatic systems are typically found in organisms and/or sediments, since metals are very insoluble at the $\mathrm{pH}$ and $\mathrm{Eh}$ of most natural waters. Benthic organisms are particularly susceptible to the effects of metal pollution since their habitat is the natural repository of metals that are transferred to the bottom in particulate form. In the sediment metals may be mobilized as a primary or secondary result of changes in redox conditions. Once mobilized, the bioavailability of a metal depends on its chemical speciation (Siegel 2002). Previous work has addressed the bioavailability of metals in offshore sediments (Neretin et al. 2004; Ye 2005; Yu 
et al. 2001) and the marine pelagic environment, but few studies have addressed the issue of metal speciation and bioavailability in bottom waters and nearshore sediment porewaters (Ellwood 2004; Gunneriusson and Sjoberg 1991).

The work reported here was carried out as part of a multipurpose geochemical mapping program dealing with chemical speciation and sedimentary processes affecting the bioavailability and bioaccumulation of toxic metals of environmental concern in Chinese coastal waters. The principal objective of the study was to determine the speciation of $\mathrm{Pb}, \mathrm{Zn}, \mathrm{Cd}$ and $\mathrm{Cr}$ in the porewaters of sediments that are the habitat of the clam, Ruditapes variegatus, and to identify responses in exposed $R$. variegatus. The $R$. variegatus selected for this research were exposed to the growth environment for a period of $\sim 3$ years to obtain information regarding which metal species were available for uptake and bioaccumulation.

\section{Materials and methods}

\section{Study site}

Jiaozhou Bay is a semi-enclosed embayment adjacent to the Yellow Sea at a latitude of $\sim 36^{\circ} \mathrm{N}$ (Fig. 1). Bound by the Shandong Peninsula on the north, it is elliptical in shape $(33.3 \mathrm{~km}$ major axis; $27.8 \mathrm{~km}$ minor axis) with an area of nearly $300 \mathrm{~km}^{2}$, an average depth of 6-7 m, and a maximum depth of $64 \mathrm{~m}$ at its mouth. Water exchange with the Yellow Sea is restricted by the fact that the mouth of the bay is only $\sim 3 \mathrm{~km}$ wide. The bay receives runoff from several streams, of which the Licun River and Haibo River on its eastern side (Fig. 1) are major sources of pollution. Sediments in the bay consist primarily of sandy silt and clayey silt (Fig. 1).

This bay was chosen for study because of concerns about pollution. Numerous chemical production plants and oil refineries are situated around Jiaozhou Bay, and the bay receives much of the permitted wastewater discharged from the city of Qingdao (population $\sim 7$ million) and surrounding areas, including domestic, agricultural, and industrial wastewater. Damage to fish farms has been caused by the heavy and sometimes extensive pollution associated with these discharges. The bay's shallow depth and restricted water exchange with the Yellow Sea have made it particularly vulnerable to impacts from pollution associated with the large human population and intensive industrialization that characterize its watershed. With respect to the present study, the presence of a large $R$. variegatus population in the bay facilitated the use of this species in the experimental design.
Sampling and chemical analysis

In June of 2003, samples of porewater, sediments, and clams (edible $R$. variegatus with a growth period of $\sim 3$ years) were collected from 12 sampling sites in the bay. The sampling protocol was as follows: (1) a Shuguang grab sampler with a sampling volume of $0.05 \mathrm{~m}^{3}$ was used to collect surface sediments to a depth of 10-15 cm; (2) the samples were centrifuged (multitube LXJ-IIB centrifuge) for $15 \mathrm{~min}$ at $3,000 \mathrm{rpm}$ to separate the sediments and porewater, and the supernatant (pore) water transferred to two bottles, one of which was acidified and preserved in a frozen state. The second bottle was kept at ambient temperature for major element analysis; (3) R. variegatus were collected using a rake-net. Sufficient and unbroken specimens were kept in a refrigerator for later use. Near-surface seawater from each sampling site was sprinkled over the $R$. variegatus to keep them moist.

Total metal concentrations in the porewater were extracted using national standard procedure (GB 17378.4, Editorial Board of National Standards Press 1998). Briefly, the $\mathrm{pH}$ of each sample was adjusted to $\sim 3-4,5 \mathrm{ml}$ of an ammonium pyrrolidine dithiocarbamate solution added, and the sample mixed by shaking. Fifty milliliter of methyl isobutyl ketone was then added and the sample shaken vigorously for $30 \mathrm{~s}$. The extracted organic layer was aspirated directly to a flame-atomic absorption spectrophotometer to determine metal concentrations. Metal concentrations in $R$. variegatus were calculated on a wet weight basis. Samples of edible tissue were initially weighed and then dried in an oven at $65^{\circ} \mathrm{C}$ to constant weight. They were then digested in concentrated nitric acid by placing them in a hot block digester at low temperature for $1 \mathrm{~h}$ and then at high temperature $\left(140^{\circ} \mathrm{C}\right)$ for at least $3 \mathrm{~h}$ (GB 17378.5, Editorial Board of National Standards Press 1998). Reagent blanks were run in all cases. Trace metals were analyzed using a flame-atomic absorption spectrophotometer. Replicated measurements were used to determine analytical precision, which was better than 5-10\%. Major elements in porewater were determined using an inductively coupled plasma (ICP) model TJA-IRISAdvantage for cations and by titration for anions.

Thermodynamic calculations

The computer program PHREEQC (David and Appelo 1999) was used to estimate the equilibrium chemical speciation of aqueous $\mathrm{Pb}(\mathrm{II}), \mathrm{Zn}$ (II), $\mathrm{Cd}$ (II), and $\mathrm{Cr}$ (III) and the $\mathrm{pH}$ and $\mathrm{Eh}$ of the porewater samples. Input variables included thermodynamic constants at $18^{\circ} \mathrm{C}$ (the average temperature of the porewaters in June 2003) and the concentrations of major anions and cations in the porewater. Basic information added to the primary PHREEQC 


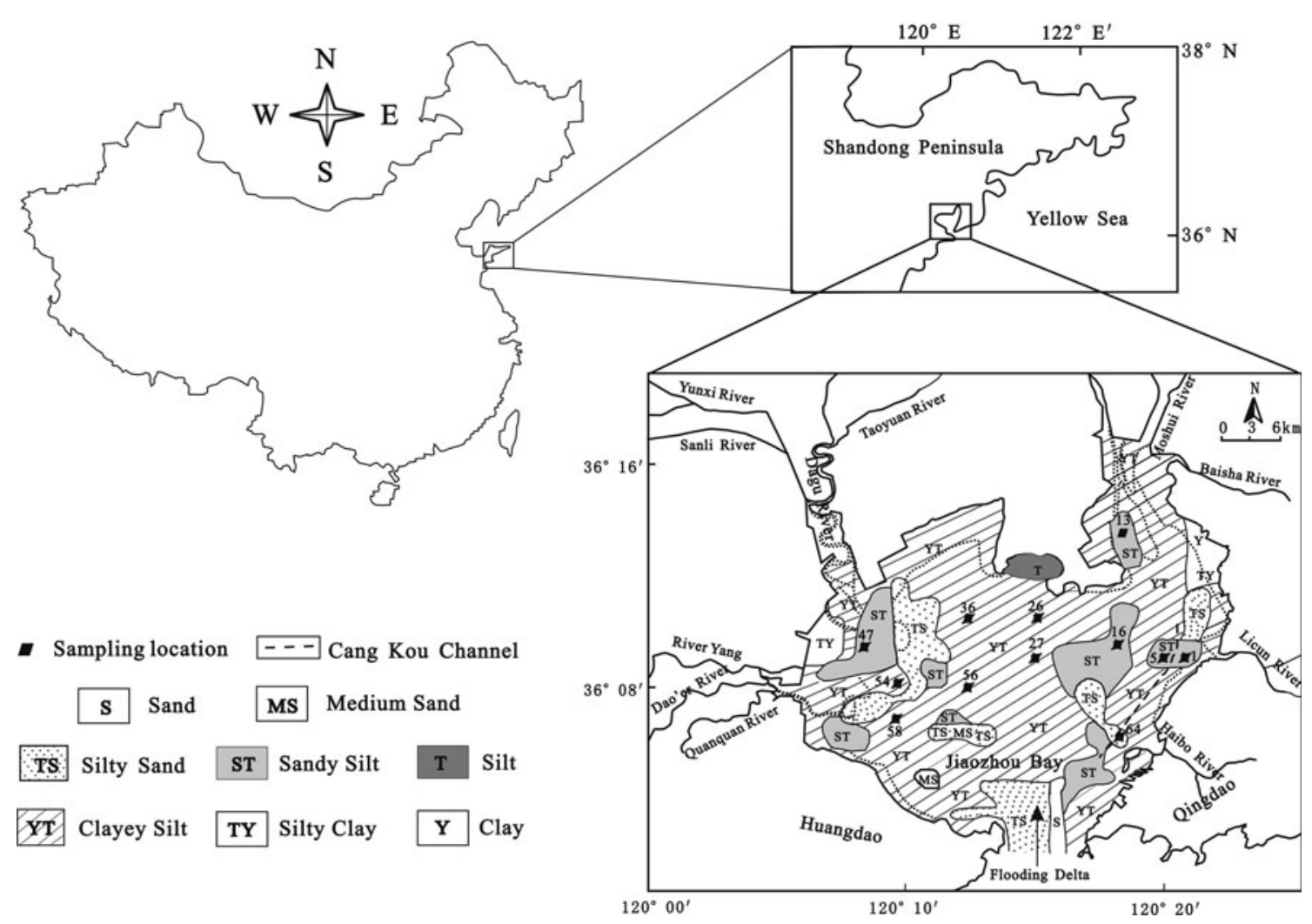

Fig. 1 Locations and distribution of the sampling sites

database included thermodynamic constants for the metals $\mathrm{Fe}, \mathrm{Mn}, \mathrm{Cu}, \mathrm{Zn}, \mathrm{Pb}, \mathrm{Cr}, \mathrm{Cd}, \mathrm{Hg}, \mathrm{Cr}$, and $\mathrm{As}$ and the corresponding potential species and their relevant reaction equations.

\section{Results}

The calculated $\mathrm{pH}$ of the porewaters varied between 7.5 and 8.1 with a mean and standard deviation of $7.8 \pm 0.2$. Calculated Eh values ranged between -32 and $-15 \mathrm{mV}$ with a mean and standard deviation of $-22 \pm 5 \mathrm{mV}$.

Porewater metal concentrations followed a bimodal distribution (Table 1), with mean values at six stations $(1,26,27,54,58$, and 64$)$ being roughly an order of magnitude higher than mean values at the other six stations $(5,13,16,36,47$, and 56). There was no consistent relationship between the high and low porewater metal concentrations and either $\mathrm{pH}$ or Eh. However, sediments at five of the six stations with high porewater metal concentrations were characterized as clayey silt, the lone exception being station 1 (sandy silt), and sediments at five of the six stations with low porewater metal concentrations were characterized as sandy silt, the lone exception being station 56 (clayey silt). The probability of such an uneven distribution of sediment types between the high and low porewater metal concentration stations is less than $5 \%$ if the null hypothesis is that the two sediment types are equally probable at all 12 stations.

Compared to the sediment porewater concentrations, metal concentrations in clam tissue were remarkably uniform. $\mathrm{Cd}, \mathrm{Cr}, \mathrm{Pb}$, and $\mathrm{Zn}$ tissue mean ( \pm standard deviation) concentrations among all stations were $126 \pm 15 \mu \mathrm{g}$ / $\mathrm{kg}, 161 \pm 45 \mu \mathrm{g} / \mathrm{kg}, 23 \pm 3 \mu \mathrm{g} / \mathrm{kg}$, and $9.6 \pm 3.5 \mathrm{mg} / \mathrm{kg}$, respectively. Despite their small variability, clam tissue metal concentrations were correlated negatively with sediment porewater metal concentrations in all four cases, and the correlations were significant at $p=0.03$ and 0.06 in the cases of $\mathrm{Cr}$ and $\mathrm{Pb}$, respectively (Fig. 2). Based on an analysis of variance (ANOVA) there was no difference in the speciation of the porewater $\mathrm{Cd}$ and $\mathrm{Cr}$ concentrations at the high and low porewater metal concentration stations ( $p>0.6$ and 0.2 for $\mathrm{Cd}$ and $\mathrm{Cr}$, respectively). However, the percentages of $\mathrm{Pb}$ and $\mathrm{Zn}$ chelated by carbonate were higher at the high porewater metal stations, and the percentages of $\mathrm{Pb}$ and $\mathrm{Zn}$ chelated by chloride and sulfate were higher at the low porewater metal stations (Table 2). 
Table 1 Means and standard errors $(\mu \mathrm{g} / \mathrm{L})$ of porewater metal concentrations

\begin{tabular}{llc}
\hline $\begin{array}{l}\text { Stations 1, 26, 27, 54, 58, } \\
\text { and } 64(\text { mean } \pm \text { standard error) }\end{array}$ & $\begin{array}{l}\text { Stations 5, 13, 16, 36, 47, } \\
\text { and } 56(\text { mean } \pm \text { standard error) }\end{array}$ \\
\hline $\mathrm{Cd}$ & $50.7 \pm 5.6$ & $2.95 \pm 0.66$ \\
$\mathrm{Cr}$ & $2.56 \pm 0.076$ & $0.195 \pm 0.070$ \\
$\mathrm{~Pb}$ & $115 \pm 18.6$ & $3.6 \pm 1.0$ \\
$\mathrm{Zn}$ & $115 \pm 18.0$ & $13.8 \pm 1.8$ \\
\hline
\end{tabular}

\section{Discussion}

Some insight concerning the relationship between metal concentrations in porewater and clam tissue can be gained by examining the ratio of the latter to the former (Table 3 ). In the case of $\mathrm{Pb}$, for example, reported biological concentration factors (BCFs) in shellfish range from 306 in blue mussels, Mytius edulis, to 4,985 in eastern oysters, Crassostrea virginica (EPA 1980c). The ratios for $\mathrm{Pb}$ in Table 3 are far lower than this range of values, and in the case of the high porewater metal stations are actually less than 1.0. The implication is that the biologically available forms of $\mathrm{Pb}$ are a very small fraction of the total dissolved lead in the porewater, or that the $\mathrm{Pb}$ taken up by the clams is derived primarily from a source other than the porewater, i.e., a source with much lower $\mathrm{Pb}$ concentrations. Although some of the species of $\mathrm{Pb}$ in the porewater are in fact a small percentage of the total $\mathrm{Pb}$ and are present at a higher
Table 2 Percentages of dissolved porewater metals chelated as indicated in cases where differences were significant between high and low porewater metal stations

\begin{tabular}{lcll}
\hline $\begin{array}{l}\text { Metal-ligand } \\
\text { complex }\end{array}$ & $\begin{array}{l}\text { High porewater } \\
\text { metals }\end{array}$ & $\begin{array}{l}\text { Low porewater } \\
\text { metals }\end{array}$ & $\begin{array}{l}\text { Type I } \\
\text { error }\end{array}$ \\
\hline $\mathrm{PbCO}_{3}$ & 81 & 70 & 0.008 \\
$\mathrm{ZnCO}_{3}$ & 27.5 & 16.9 & 0.009 \\
$\mathrm{PbCl}^{+}$ & 7.2 & 13.4 & 0.010 \\
$\mathrm{ZnCl}^{+}$ & 11.1 & 16.2 & 0.019 \\
$\mathrm{PbCl}_{2}$ & 4.4 & 8.2 & 0.014 \\
$\mathrm{ZnCl}_{2}$ & 3.8 & 5.6 & 0.029 \\
$\mathrm{PbCl}_{3}{ }^{-}$ & 1.0 & 2.1 & 0.021 \\
$\mathrm{ZnCl}_{3}{ }^{-}$ & 1.4 & 2.1 & 0.043 \\
$\mathrm{PbSO}_{4}$ & 0.93 & 1.91 & 0.010 \\
$\mathrm{ZnSO}_{4}$ & 10.7 & 15.6 & 0.017 \\
\hline
\end{tabular}

percentage at the low porewater metal stations, the difference in percentages between the high and low porewater metal stations is no more than roughly a factor of 2 , which is not enough to explain the $9.9 / 0.34=29$-fold difference in tissue/porewater ratios between the two sets of stations if the porewater were the source of the $\mathrm{Pb}$ taken up by the clams.

Reported $\mathrm{BCFs}$ for $\mathrm{Cd}$ in bivalve mollusks range between 83 for the hard-shelled clam, Mercenaria mercenaria, to 3,650 for the eastern oyster, Crassostrea virginica (EPA 1980b). This range of values is far above the
Fig. 2 Porewater metal concentrations versus clam tissue metal concentrations. Straight lines are regressions fit to data in cases where correlations were significant
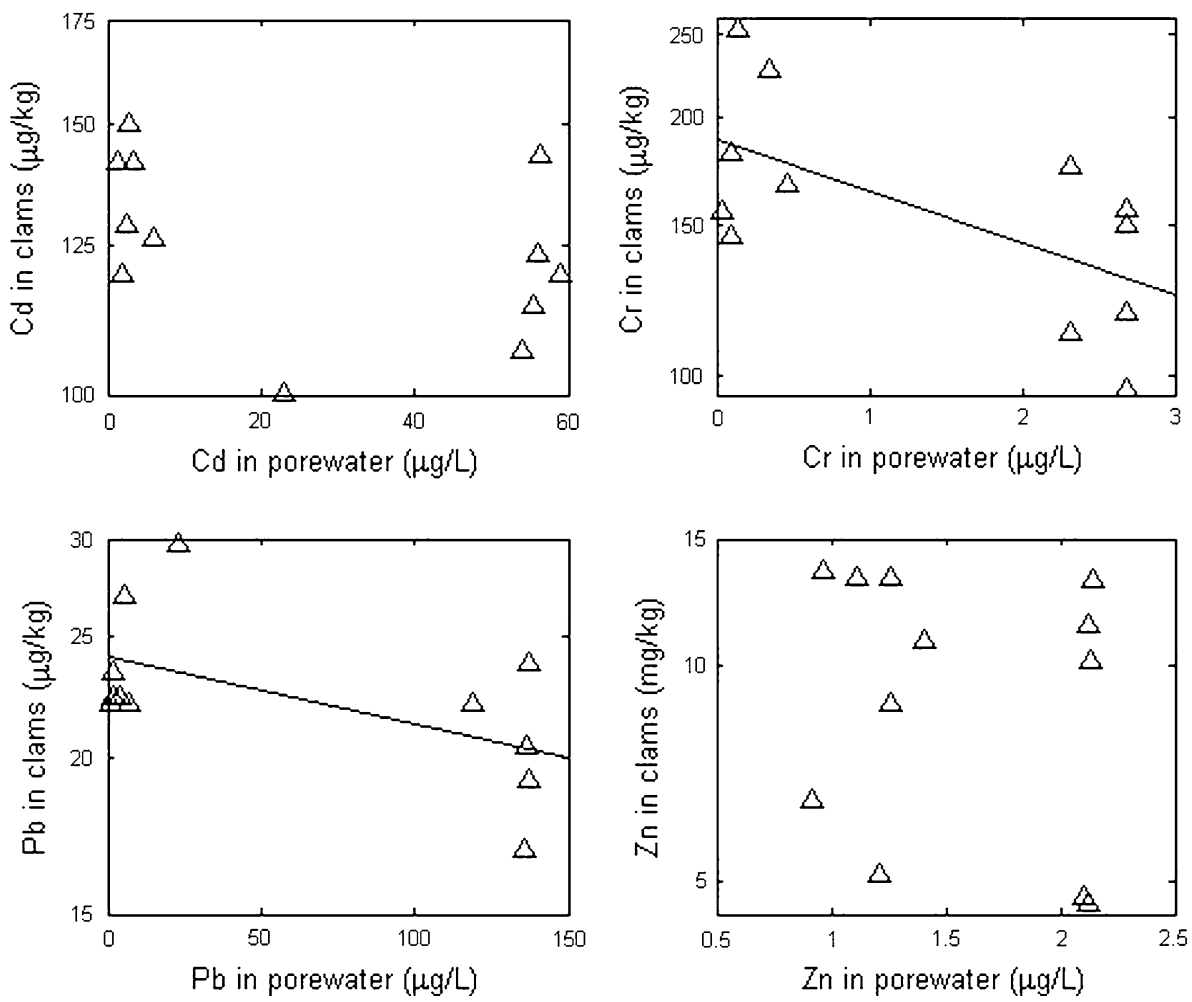
Table 3 Ratio of metal concentrations in clams to sediment porewater (mean \pm standard error)

\begin{tabular}{lllll}
\hline & $\mathrm{Cd}$ & $\mathrm{Cr}$ & $\mathrm{Pb}$ & $\mathrm{Zn}$ \\
\hline $\begin{array}{c}\text { High porewater } \\
\text { metal stations }\end{array}$ & $2.5 \pm 0.4$ & $53 \pm 6$ & $0.34 \pm 0.19$ & $125 \pm 60$ \\
$\begin{array}{c}\text { Low porewater } \\
\text { metal stations }\end{array}$ & $58 \pm 13$ & $1,725 \pm 508$ & $9.9 \pm 2.7$ & $798 \pm 164$ \\
\hline
\end{tabular}

corresponding figure of 2.5 at the high porewater metal stations, and because the speciation of $\mathrm{Cd}$ was not significantly different at the high and low porewater metal stations, there is no way to explain the $58 / 2.5=23$-fold difference in clam tissue/porewater ratios between the two sets of stations if the porewater were the source of the $\mathrm{Cd}$ taken up by the clams.

Reported BCFs for trivalent $\mathrm{Cr}$ in bivalve mollusks range between 86 and 153 (EPA 1980a). These are less than three times the corresponding tissue/porewater ratio of 53 at the high porewater metal stations and well below the ratio of 1,725 at the low porewater metal stations. However, because the speciation of $\mathrm{Cr}^{3+}$ was not significantly different between the two sets of stations, there is no way to explain the $1,725 / 53=33$-fold difference in clam tissue/porewater ratios between the two sets of stations if the porewater were the source of the $\mathrm{Cr}$ taken up by the clams.

Reported BCFs for $\mathrm{Zn}$ in shellfish range from 107 in the soft-shell clam, Mya arenaria, to 20,500 in the eastern oyster, Crassostrea virginica (EPA 1987). If BCFs on the order of 100 are typical of clams, the ratios in Table 3 for $\mathrm{Zn}$ are plausible. Although some of the species of $\mathrm{Zn}$ in the porewater are present at a higher percentage at the low porewater metal stations, the difference in percentages between the high and low porewater metal stations is no more than a factor of 1.5 , which is not enough to explain the $798 / 125=6.4$-fold difference in tissue/porewater ratios between the two sets of station if the porewater were the source of the $\mathrm{Zn}$ taken up by the clams.

The implication of this analysis is that the sediment porewater is not the primary source of the metals taken up by $R$. variegatus. The spatially rather uniform concentrations of metals in the clams presumably reflects the fact that, despite the localized nature of metal inputs from sources primarily along the eastern side of the bay, metal concentrations to which the clams are exposed are relatively uniform as a result of mixing processes within the bay. The bimodal distribution of sediment porewater metal concentrations is closely correlated with the granularity of the sediment, with lower porewater metal concentrations associated with coarser sediment. The most likely explanation for this correlation is the fact that under oxidizing conditions the metals of interest in this study would tend to
Table 4 Comparison of FDA action levels with metal concentrations in $R$. variegates $(\mu \mathrm{g} / \mathrm{g})$

\begin{tabular}{lcl}
\hline Metal & $\begin{array}{l}\text { Action level } \\
\text { (FDA 2001) }\end{array}$ & $\begin{array}{l}\text { Mean concentration in } \\
\text { R. variegatus from Jiaozhou Bay }\end{array}$ \\
\hline $\mathrm{Cd}$ & 4 & 0.126 \\
$\mathrm{Cr}$ & 13 & 0.161 \\
$\mathrm{~Pb}$ & 1.7 & 0.023 \\
\hline
\end{tabular}

be scavenged by insoluble forms of oxidized iron and manganese. Under reducing conditions iron and manganese would be reduced to soluble $\mathrm{Fe}^{2+}$ and $\mathrm{Mn}^{2+}$, respectively, and metals scavenged under oxidizing conditions would be released to the porewater (C. Measures, personnel communication). The nature of sampling the sediment (grab samples to a depth of 10-15 cm) likely precluded detection of this effect in terms of porewater Eh, but it seems reasonable to assume that the transition to reducing conditions would occur at a greater depth in coarse than fine-grained sediment.

The two exceptions to this paradigm are stations 1 and 56. The high porewater metal concentrations at station 1 most likely reflect its location near the mouth of the Licun River, which is a major source of heavy metal pollution as a result of industrial activities within its watershed. Station 56 , on the other hand, is located near the geographical center of the bay and hence far from any point-source inputs.

Finally, it is of interest to ask whether $R$. variegatus harvested from Jiaozhou Bay would represent a hazard to human health if consumed. To address this question, we compared the concentrations of $\mathrm{Cd}, \mathrm{Cr}$, and $\mathrm{Pb}$ measured in this study with the so-called action levels of the United States Food and Drug Administration (FDA) (Table 4). It is apparent from this comparison that the concentrations of these metals in $R$. variegatus are roughly two orders of magnitude lower than the FDA action levels and hence of no concern from a human health standpoint.

\section{Conclusions}

The range of Eh and $\mathrm{pH}$ were both sufficiently small with the range of -32 to $-15 \mathrm{mv}$ for the former, and the 7.5-8.1 for the latter. Porewater concentrations of given metals followed a bimodal distribution with mean values at six stations being roughly an order of magnitude higher than mean values at the other six stations. There was no consistent relationship between porewater metal concentrations and either $\mathrm{pH}$ or $\mathrm{Eh} . \mathrm{Pb}, \mathrm{Zn}$ and $\mathrm{Cd}$ in porewater were present only in the +2 state, and $\mathrm{Cr}$ in the +3 state. The percentages of carbonato complexes of $\mathrm{Pb}$ and $\mathrm{Zn}$ 
were higher at the high porewater metal stations, and the percentages of chloro and sulfato conplexes of $\mathrm{Pb}$ and $\mathrm{Zn}$ were higher at the low porewater metal stations. Metal concentrations in clam tissue were remarkably uniform, but clam tissue concentrations were correlated negatively with porewater metal concentrations in all cases, and the correlations were significant at $p=0.03$ and 0.06 in the cases of $\mathrm{Cr}$ and $\mathrm{Pb}$. The porewaters were not the primary sources of the metals in the clams. The porewater diffusion layer likely accounts for the rather uniform concentrations of $\mathrm{Pb}$, $\mathrm{Zn}, \mathrm{Cd}$ and $\mathrm{Cr}$ in clam tissue.

Acknowledgments This paper was made possible by the National Natural Science Foundation of China (40872167), China Geologic Survey (CGS) project (1212010611402) and Key Laboratory of Marine Hydrocarbon Resources and Environmental Geology, Ministry of Land and Resources (MRE200920).

Open Access This article is distributed under the terms of the Creative Commons Attribution Noncommercial License which permits any noncommercial use, distribution, and reproduction in any medium, provided the original author(s) and source are credited.

\section{References}

David LP, Appelo CAJ (1999) User's guide of PHREEQC-A computer program for speciation, batch-reaction, one-dimensional transport, and inverse geochemical calculations. US Geological Survey

Editorial Board of National Standards Press (1998) National standards. National Standards Press, Beijing (in Chinese)

EI-Moselhy KM, Gabal MN (2004) Trace metals in water, sediments and marine organisms from the northern part of the Gulf of Suez, Red Sea. J Mar Syst 46:39-46

Ellwood MJ (2004) Zinc and cadmium speciation in subantarctic waters east of New Zealand. Mar Chem 87:37-58
EPA (1980a) Ambient water quality criteria for chromium. EPA 440/ 5-80-035, Washington, DC

EPA (1980b) Ambient water quality for cadmium. EPA 440/5-80025, Washington, DC

EPA (1980c) Ambient water quality for lead. EPA-440/4-80-057, Environmental Protection Agency, Washington, DC

EPA (1987), Ambient Water Quality Criteria for Zinc. EPA-440/587-003, Washington, DC

FDA (2001) Fish and fisheries products hazards and controls guidance, 3rd edn. United States Department of Health and Human Services, Washington, DC

Franco DR, Berquo TS, Imbernon RAL, Partiti CSM, Enzweiler J (2007) Environmental monitoring of magnetic iron phases of urban water reservoir lake sediments (Taiaçupeba Lake, metropolitan region of Sao Paulo, Brazil) by using Mossbauer spectroscopy. Environ Geol 52:831-842

Gunneriusson L, Sjoberg S (1991) Equilibrium speciation models for $\mathrm{Hg}, \mathrm{Cd}$, and $\mathrm{Pb}$ in the Gulf of Bothnia and its catchment area. Nordic Hydrol 22:67-80

Heier LS, Lien IB, Stronmseng AE (2009) Speciation of lead, copper, zinc and antimony in water draining a shooting range-time dependant metal accumulation and biomarker responses in brown trout (Salmo trutta L.). Sci Total Environ 407:4047-4055

Neretin LN, Bottcher ME, Jorgensen BB (2004) Pyritization processes and greigite formation in the advancing sulfidization front in the Upper Pleistocene sediments of the Black Sea. Geochim Cosmochim Acta 68(9):2081-2093

Siegel FR (2002) Environmental geochemistry of potentially toxic metals. Springer, Germany

Szeffer P, Wolowicz M, Kusak A, Deslous-Paoli JM, Czarnowski W, Frelek K, Belzunce MJ (1999) Distribution of mercury and other trace metals in th cockle Cerastoderma glaucum from the Mediterranean Lagoon Etangde Thau. Arch Environ Contam Toxicol 36:56-63

Ye S (2005) Biogeochemical cycles of trace metals in aquatic ecosystems and its ecologic effects in Jiaozhou Bay. Original research thesis, China University of Ming and Technology, Beijing

Yu K, Tsal LJ, Chen S (2001) Chemical binding of heavy metals in anoxic river sediments. Water Res 35(17):4086-4094 